\title{
Comparison of Ankaferd Blood Stopper and silver sulfadiazine use in burn wounds: An experimental study
}

\author{
단 Serden Ay, M.D., ${ }^{1}$ 나 Yaşar Ünlü, M.D. ${ }^{2}$
}

${ }^{1}$ Department of General Surgery, KTO Karatay University Faculty of Medicine, Konya-Turkey

${ }^{2}$ Department of Pathology, Health Sciences University Konya Training and Research Hospital, Konya-Turkey

\begin{abstract}
BACKGROUND: The present study was designed to compare the effectiveness of topical silver sulfadiazine (SSD) and Ankaferd Blood Stopper ${ }^{\circledR}$ (ABS) usage in experimental partial-thickness burns in rats.

METHODS: Twenty-one male Wistar albino rats weighing 250-290 (range: 270 19 ) g were used in the present study. A round brass probe that was specifically designed $(3 \times 3 \mathrm{~cm}$ diameter) was used to induce the burns in rats. After the presence of partial-thickness burns was confirmed, the rats were divided into three groups: Group I (ABS group) Ankaferd Blood Stopper ${ }^{\circledR}$ pad, Group 2 (SSD group) silver sulfadiazine (Silverdin ${ }^{\circledR}$ ), and Group 3 (Control group) I\% isotonic saline solution-impregnated pad. The healing period was followed up clinically and histopathologically. The day on which $50 \%$ and $80 \%$ of re-epithelization at first were detected for each rat was also recorded.
\end{abstract}

RESULTS: The mean times of $50 \%$ and $80 \%$ of re-epithelization at first were 10.8 days, 13.8 days, and I6.8 days in Groups I, 2 , and 3 , respectively $(p<0.00 \mathrm{I})$, and 16.4 days, 19.7 days, and 25.2 days, respectively $(p<0.00 \mathrm{I})$. The mean inflammatory scores were also found to be better in the ABS group than in other groups $(p<0.05)$.

CONCLUSION: Our study showed that ABS has better results for the healing of the burn wound than SSD in experimental partialthickness burns in rats.

Keywords: Ankaferd Blood Stopper; burn; experimental study; silver sulfadiazine.

\section{INTRODUCTION}

Burn injuries, an important global public health issue, are still considered to be among the most destructive of all types of injuries. The main goal of the treatment of burns is a fast epithelization and wound healing to prevent secondary infections, as well as to reduce the functional and aesthetic issues. On the other hand, the likelihood of occurrence of deformities, mis-formation, and infection at the burn site of the wound are the main concerns toward their implementation. ${ }^{[1]}$

Topical agents may decrease the morbidity and mortality rates by preventing sepsis and bacterial contamination during the healing process of the burn wounds. Currently, in severe burns, silver sulfadiazine (SSD) as a topical agent is used worldwide. ${ }^{[2]}$ In addition to its effectiveness, SSD cream has some important systemic complications, such as neutropenia, erythema multiforme, methemoglobinemia, and crystalluria. ${ }^{[3]}$

Ankaferd Blood Stopper (ABS) (İmmun İlaç Kozmetik Ltd., Istanbul, Turkey) is a traditional and unique medicinal plant extract that has historically been used in Turkey as a hemostatic agent. ${ }^{[4]}$ The promising result of $A B S$ in promoting tissue healing has been shown in several studies recently. ${ }^{[5]}$ Thus, the aim of the experimental study was to compare the effectiveness of topical ABS and SSD in partial-thickness burns in rats.

\section{MATERIALS AND METHODS}

After obtaining permission from the ethical board of our uni-

Cite this article as: Ay S, Ünlü Y. Comparison of Ankaferd Blood Stopper and silver sulfadiazine use in burn wounds: An experimental study. Ulus Travma Acil Cerrahi Derg 2019;25:338-342.

Address for correspondence: Serden Ay, M.D.

Hacı Şaban Mah., Meram Yeniyol Cad., No: 97, 42040 Meram, Konya, Turkey

Tel: +90332 - 3236709 E-mail: serdenay@yahoo.com

Ulus Travma Acil Cerrahi Derg 2019;25(4):338-342 DOI: 10.14744/tjtes.2019.38265 Submitted: 19.1I.2018 Accepted: 24.05.2019 Online: 08.07.2019

Copyright 2019 Turkish Association of Trauma and Emergency Surgery 
versity, the study was designed according to the Health Guide for the Care and Use of Laboratory Animals by the National Institutes of Health (NIH publication no.: 86-23, revised 1985, Bethesda) criteria. The study was completed at the Experimental Research Center of Necmettin Erbakan University. A total of 21 male Wistar albino rats weighing 250-290 (range: $270 \pm 19) \mathrm{g}$ were used for the study. The rats were kept at an equal hour light and dark cycle at a temperature of $22{ }^{\circ} \mathrm{C}-26{ }^{\circ} \mathrm{C}$. They were given a standard rat diet. By means of drinking water, $100 \mathrm{mg} / 5 \mathrm{~mL}$ ibuprofen was administered as an analgesic after the burn formation. The rats were set up individually and approached with appropriate equipment to prevent contamination.

Anesthesia was administered by a single dose of $50 \mathrm{mg} / \mathrm{kg}$ ketamine hydrochloride (Ketalar $50 \mathrm{mg} / \mathrm{mL}$; Parke-Davis, $\mathrm{MI}$, USA) and $6 \mathrm{mg} / \mathrm{kg}$ intramuscular xylazine hydrochloride (Rompun $23.32 \mathrm{mg} / \mathrm{mL}$; Bayer, Leverkusen, Germany). The back region of the rats was shaved and cleaned with a $10 \%$ povidone-iodine solution (Kim-Pa, Poviiodeks, $10 \%$ povidone-iodine). A specifically designed round brass probe ( $3 \times 3 \mathrm{~cm}$ diameter) was used to induce the burns (Fig. I). After sterilization in boiling water for $5 \mathrm{~min}$, the probe was applied with no pressure to the skin of anesthetized rats for I5 s. With this procedure, second-degree partial-thickness burns were formed. After the burns were formed, all the rats were placed and kept in individual cages and divided into three groups. Ankaferd Blood Stopper ${ }^{\circledR}$ pad was used in Group I (ABS group), silver sulfadiazine (Silverdin ${ }^{\circledR}$; Toprak Drug Co., Turkey) I\% in Group 2 (SSD group), and isotonic saline solution-impregnated pads in Group 3 (Control group). The healing period was observed clinically and histopathologically.

To specify the wound healing process, two parameters were used as follows:

I. the exact day on which $50 \%$ and $80 \%$ of re-epithelization were detected at first

2. histopathological changes.

The study period did not end until 4 weeks after the burns were observed. Digital photos of the burns were taken with

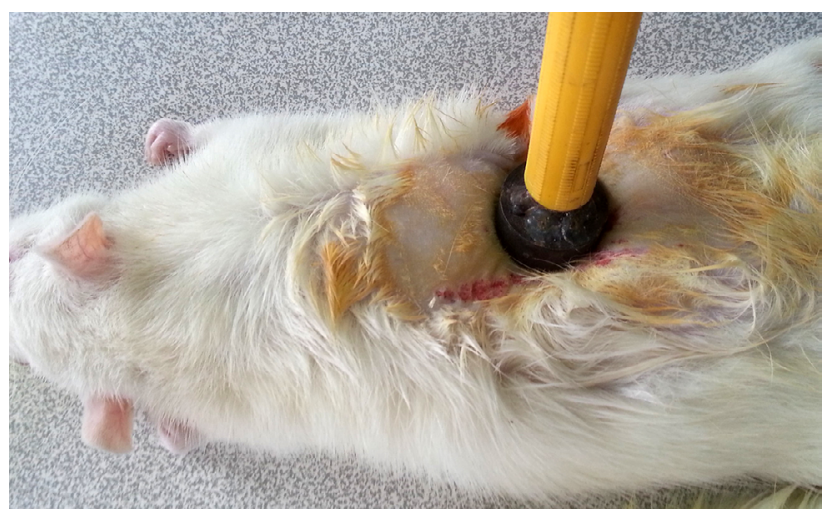

Figure 1. The application of brass and burn formation. a camera every day 3 of the follow-up. On week 4 of the follow-up period, for histological evaluation, skin samples were obtained at the same distance and under the same conditions. The healing process of the burns was evaluated by the same clinician who is experienced on burn and blinded to the study. The measurements of the burn areas were evaluated using the NIH ImageJ program as described in our previous study. ${ }^{[6]}$ The percentage of re-epithelization was calculated as follows:

Percentage of re-epithelization=first burn area-current burn area/first burn area.

The $50 \%$ and $80 \%$ of re-epithelization rates were recorded precisely until the end of the study. All the rats were sacrificed after the photos were taken on week 4 of the study. The resected full-thickness skin samples were collected from the burn areas. Histological parameters (epithelialization, polymorphonuclear neutrophil (PMN), angiogenesis, and fibrosis) were evaluated on biopsy specimens of the wounds at the end of the study as follows: for fibrosis (collagen bundles): normal bundle: 2, disorganized/edematous: I, and amorphous: 0 and for PMN: 40× field: 0-10: 2, II-40: I, and >40: 0 .

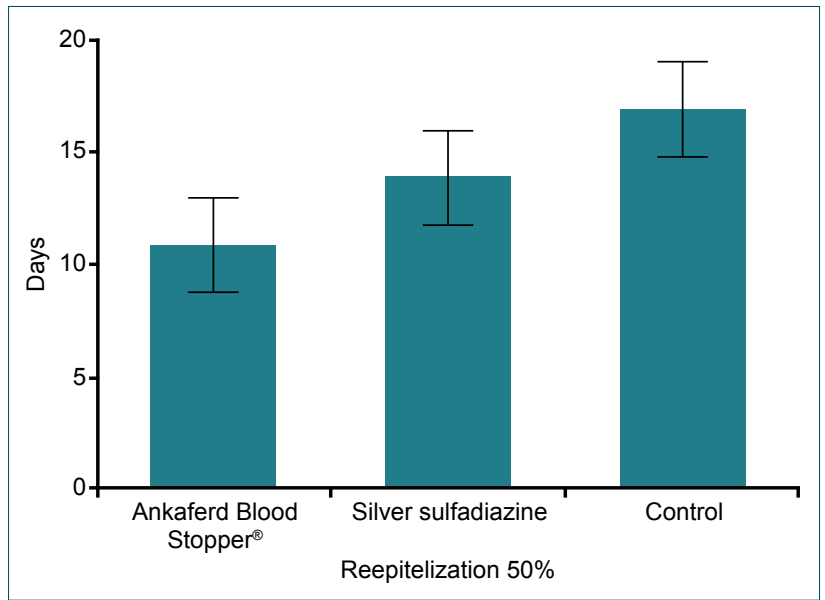

Figure 2. Times to $50 \%$ of re-epithelization.

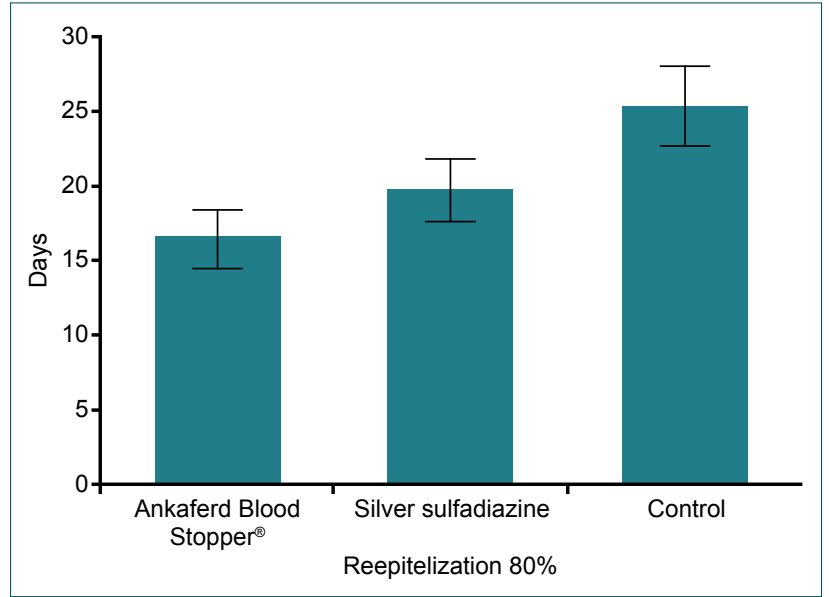

Figure 3. Times to $80 \%$ of re-epithelization. 
Table I. Inflamation and collagen scores of the groups

\begin{tabular}{lcccc}
\hline Characteristic & $\begin{array}{c}\text { Group } \\
\text { ABS }\end{array}$ & $\begin{array}{c}\text { Group } \\
\text { SSD }\end{array}$ & $\begin{array}{c}\text { Control } \\
\text { group }\end{array}$ & p \\
\hline Inflammation scores & $\mathrm{I} .71 \pm 0.48$ & $0.85 \pm 0.37$ & $0.28 \pm 0.48$ & $<0.001$ \\
Collagen bundles & $\mathrm{I} .85 \pm 0.37$ & $\mathrm{I} .28 \pm 0.48$ & $0.42 \pm 0.53$ & $<0.001$
\end{tabular}

ABS: Ankaferd Blood Stopper ${ }^{\circledR}$; SSD: Silver sulfadiazine.

Data were analyzed by using Statistical Package for the Social Sciences (SPSS) 19.0 for Windows program (SPSS Inc., Chicago, IL, USA). One-way ANOVA and Tukey's post hoc test were used to analyze the data. A p value $<0.05$ was considered as statistically significant.

\section{RESULTS}

The mean times for $50 \%$ of re-epithelization at first were 10.8 days, 13.8 days, and 16.8 days in the ABS group, SSD group, and control group, respectively $(p<0.00 \mathrm{I})$ (Fig. 2), and for $80 \%$ of re-epithelization at first were 16.4 days, 19.7 days, and 25.2 days, respectively $(\mathrm{p}<0.00 \mathrm{I}$ ) (Fig. 3). The ABS group had faster healing duration than the other groups with respect to $50 \%$ and $80 \%$ of re-epithelization (Fig. 4). These differences were statistically significant. The SSD group had also better healing rates than the control group based on $50 \%$ and $80 \%$ of re-epithelization of the burn. The mean inflammatory scores revealed a significant difference in the ABS group compared with the others $(p<0.05)$. The collagen scores were also higher in the ABS group than in the other groups (Table I) $(\mathrm{p}<0.05)$ (Fig. 5a-c).

\section{DISCUSSION}

The overall process of burn healing is similar with that seen in the wound healing process which generally follows the phases of inflammation, proliferation, and remodeling. This healing process can be obstructed due to many reasons. Miscellaneous studies have shown that infection not only is the main cause for the failure of healing but also can increase the risk of mortality among burn patients. ${ }^{[7]}$ Thus far, many investiga-

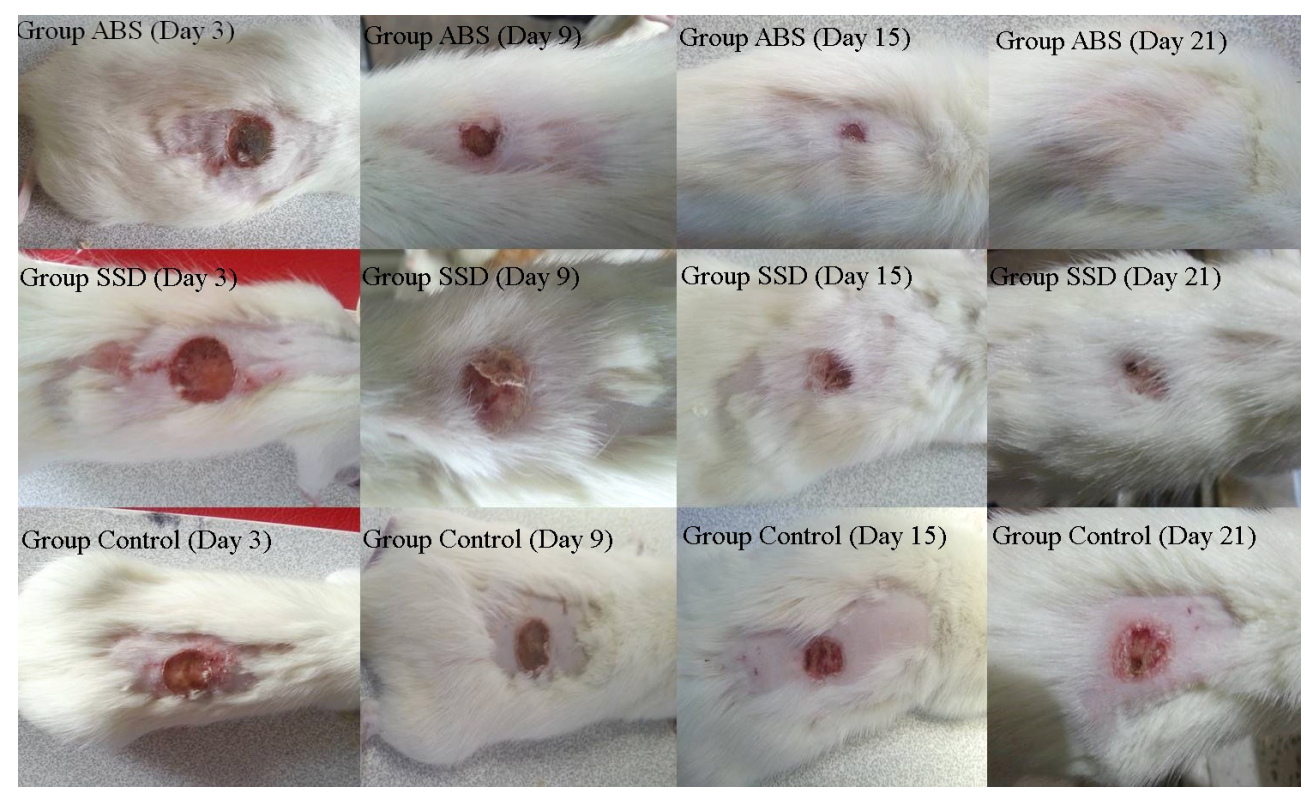

Figure 4. Burn wounds on days 3, 9, 15, and 21.
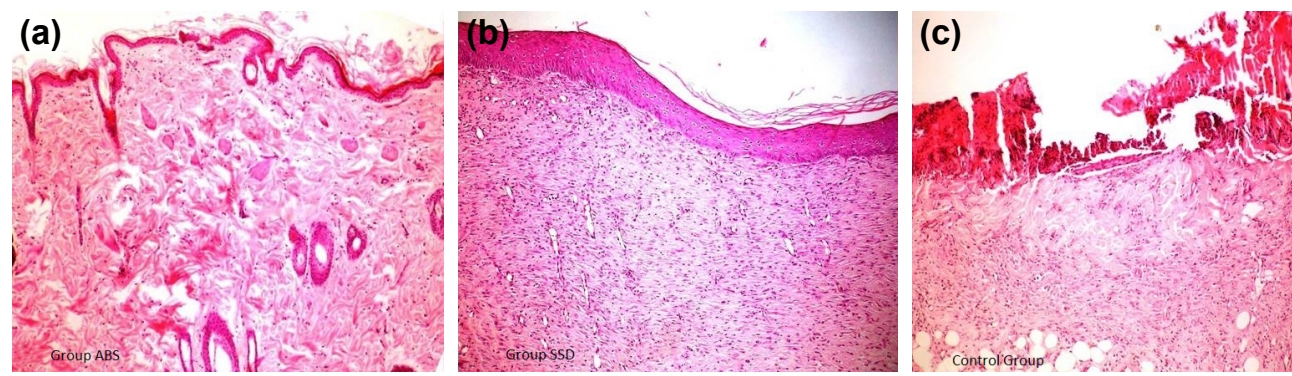

Figure 5. (a) Beneath the preserved epidermis, within the dermis infiltrated with mild fibrosis and inflammation, adnexas can be chosen (ABS group). (b) Beneath the preserved epidermis, within the dermis infiltrated with partial fibrosis and inflammation, adnexas cannot be observed (SSD group). (c) At the end of 4 weeks, beneath the epidermis, which is not well-preserved, obvious fibrosis and inflammation can be observed, and adnexas are not visible (Control group). 
tions have been conducted to understand how to prevent secondary infection and to accelerate the healing process. Usage of topical antibiotics has already been determined as effective in preventing mortality. ${ }^{[8]}$ SSD, one of the popular topical antibiotics, is convenient widely and easy to use, gives no pain, and has low toxicity while showing a good antibacterial effect. Therefore, SSD is the gold standard as an antimicrobial topical ointment in burn patients now. ${ }^{[9]}$ In addition to its antimicrobial effect, SSD has a positive effect on the proliferation of fibroblasts producing collagen and fibronectin and stimulates the production of growth factor and cytokines from cells, such as macrophages during the wound healing process. ${ }^{[10]} \mathrm{How}-$ ever, there are some side effects of SSD, such as neutropenia, erythema multiforme, crystalluria, and methemoglobinemia, and can delay the wound healing process. ${ }^{[3]}$

On the other hand, the healing of the burn wound is still controversial. There are only a few drugs ruling the physiological wound healing defined to be effective. ${ }^{[I]}$ In the past few years, the effect of some herbal medicine on burn wounds has been investigated widely, and several products derived from plants have been shown to have strong wound healing effects. ${ }^{\left[{ }^{\prime \prime}\right]}$ While most of the medicines are a mixture of several plants, none of these traditional ointments were studied prominently. In the present study, ABS was compared with SSD as a standard treatment for burns in rats.

$A B S$, a unique traditional herbal medicine that has been consumed for many years in Anatolia as a hemostatic agent, was certified by the Turkish Ministry of Health in October 2007. [12] $A B S$ is a standardized mixture of the plants Alpinia officinarum, Thymus vulgaris, Vitis vinifera, Urtica dioica, and Glycyrrhiza glabra. Each of these plants ABS consumes has some various beneficial effect on blood cells, endothelium, cellular proliferation, angiogenesis, cell mediators, and/or vascular dynamics. ${ }^{[13]}$ In addition to its hemostatic activity, ABS may also prevent bacterial growth. ${ }^{[14]}$ In a previous study, the antimicrobial activity of ABS was tested against 102 clinical isolates, which reported that $A B S$ was active against all of these isolates, and the zones of inhibition were within a range of 8-10 mm diameter. ${ }^{[15]}$ The antibacterial efficiency of ABS toward Gram-negative and Gram-positive food, as well as human pathogens, has also been determined. ${ }^{[14]}$ Neither systemic nor local adverse effects and/or toxicity have been seen in association with anecdotal and experimental topical uses of ABS. Hematotoxicity, acute mucosal toxicity, nephrotoxicity, hepatotoxicity, and biochemical toxicity have not also been defined during the short-term follow-up of animals. ${ }^{[14]}$

The comparison between the groups in our study showed that $A B S$ was statistically significantly superior with respect to histopathological evaluation and recovery duration compared with the previously proven SSD. Kaya et al. ${ }^{[6]}$ and Topal et al. ${ }^{[17]}$ have previously demonstrated that even though the ABS and control groups are similar with respect to wound healing on day $7, A B S$ is statistically superior on day 14. In contrast, Topal et al. ${ }^{[17]}$ could not determine any difference between ABS and SSD in burn wounds. On the other hand, in our study, ABS had a shorter recovery time than SSD based on $50 \%$ and $80 \%$ of re-epithelization rates. In our opinion, $A B S$ may have a superior beneficial effect and can be widely used in the treatments of burn injuries, instead of SSD usage.

\section{Conflict of interest: None declared.}

\section{REFERENCES}

1. Rowan MP, Cancio LC, Elster EA, Burmeister DM, Rose LF, Natesan S, et al. Burn wound healing and treatment: review and advancements. Crit Care 2015;19:243. [CrossRef]

2. Papini RP, Wilson AP, Steer JA, McGrouther DA, Parkhouse N. Wound management in burn centres in the United Kingdom. Br J Surg 1995;82:505-9. [CrossRef]

3. Atiyeh BS, Costagliola M, Hayek SN, Dibo SA. Effect of silver on burn wound infection control and healing: review of the literature. Burns 2007;33:139-48. [CrossRef]

4. Goker H, Haznedaroglu IC, Ercetin S, Kirazli S, Akman U, Ozturk Y, et al. Haemostatic actions of the folkloric medicinal plant extract Ankaferd Blood Stopper. J Int Med Res 2008;36:163-70. [CrossRef]

5. Akalin C, Kuru S, Barlas AM, Kismet K, Kaptanoglu B, Demir A, et al. Beneficial effects of Ankaferd Blood Stopper on dermal wound healing: an experimental study. Int Wound J 2014;11:64-8. [CrossRef]

6. Arslan K, Karahan O, Okuş A, Unlü Y, Eryılmaz MA, Ay S, et al. Comparison of topical zinc oxide and silver sulfadiazine in burn wounds: an experimental study. Ulus Travma Acil Cerrahi Derg 2012;18:376-83.

7. Velnar T, Bailey T, Smrkolj V. The wound healing process: an overview of the cellular and molecular mechanisms. J Int Med Res 2009;37:1528-42.

8. D'Avignon LC, Saffle JR, Chung KK, Cancio LC. Prevention and management of infections associated with burns in the combat casualty. $\mathrm{J}$ Trauma 2008;64:S277-86. [CrossRef]

9. Kimura Y, Sumiyoshi M, Kawahira K, Sakanaka M. Effects of ginseng saponins isolated from Red Ginseng roots on burn wound healing in mice. Br J Pharmacol 2006;148:860-70. [CrossRef]

10. Nascimento EG, Sampaio TB, Medeiros AC, Azevedo EP. Evaluation of chitosan gel with $1 \%$ silver sulfadiazine as an alternative for burn wound treatment in rats. Acta Cir Bras 2009;24:460-5. [CrossRef]

11. Akhoondinasab MR, Akhoondinasab M, Saberi M. Comparison of healing effect of aloe vera extract and silver sulfadiazine in burn injuries in experimental rat model. World J Plast Surg 2014;3:29-34.

12. Kandemir O, Buyukates M, Kandemir NO, Aktunc E, Gul AE, Gul S, et al. Demonstration of the histopathological and immunohistochemical effects of a novel hemostatic agent, Ankaferd Blood Stopper, on vascular tissue in a rat aortic bleeding model. J Cardiothorac Surg 2010;5:110.

13. Beyazit Y, Kekilli M, Haznedaroglu IC, Kayacetin E, Basaranoglu M. Ankaferd hemostat in the management of gastrointestinal hemorrhages. World J Gastroenterol 2011;17:3962-70. [CrossRef]

14. Bilgili H, Captug O, Kosar A, Kurt M, Kekilli M, Shorbagi A, et al. Oral systemic administration of Ankaferd blood stopper has no short-term toxicity in an in vivo rabbit experimental model. Clin Appl Thromb Hemost 2010;16:533-6. [CrossRef]

15. Tasdelen Fisgin N, Tanriverdi Cayci Y, Coban AY, Ozatli D, Tanyel E, Durupinar B, et al. Antimicrobial activity of plant extract Ankaferd Blood Stopper. Fitoterapia 2009;80:48-50. [CrossRef]

16. Kaya H, Gokdemir M, Sogut O, Demir T, Kocarslan S. Effects of Folk Medicinal Plant Extract Ankaferd Blood Stopper On Burn Wound Healing. Acta Medica Mediterranea 2013:29;497-502.

17. Topal A, Gul Satar NY, Cangul T, Ayberk Oktay M, Inan K, Cecen G, et al. Ankaferd blood stopper accelerates deep second degree burn wound healing in rats. Acta Veterinaria Brno 87:261-7. [CrossRef] 
DENEYSEL ÇALIŞMA - ÖZET

Yanık yarası tedavisinde Ankaferd Blood Stoper ile gümüşs sülfadiazinin karşılaştırılması: Deneysel çalışma

Dr. Serden Ay, ${ }^{1}$ Dr. Yaşar Ünlü ${ }^{2}$

${ }^{1}$ KTO Karatay Üniversitesi Tıp Fakültesi, Genel Cerrahi Anabilim Dalı, Konya

${ }^{2}$ Sağıık Bilimler Üniversitesi, Konya Eğitim ve Araştırma Hastanesi, Patoloji Kliniği, Konya

AMAÇ: Bu deneysel çalışma yanık yaralarında Ankaferd Blood Stoper ve gümüş sülfadiazinin (SSD) etkinliğini karşılaştırmak üzere dizayn edilmiştir. GEREÇ VE YÖNTEM: Çalışma için Wistar albino cinsi 2 I sıçan kullanıldı. Yanık oluşturmak için $3 \times 3 \mathrm{~cm}$ çapında yuvarlak özel dizayn edilmiş pirinç prob kullanıldı. Yanık oluşturulduktan sonra, sıçanlar üç gruba ayrıldı. Ankaferd Blood Stoper (Grup ABS) grup I'de, Gümüş sülfadiazin (Grup SSD) grup 2'de, izotonik emdirilmiş spançlarda (Grup kontrol) grup 3'de kullanıldı. lyilişme dönemi klinik ve histoplatolojik olarak takip edildi. Yara ölçümleri yapıldı, \%50 ve \%80 re-epitelizasyona ulaştığı günler her sıçan için belirlendi.

BULGULAR: Ortalama \%50 re-epitelizasyon zamanı sırasıyla ABS grubu için 10.8 gün, SSD grubu için I3.8 gün ve kontrol grubu için I6.8 gündü $(p<0.001)$. Yine ortalama \%80 re-epitelizasyon zamanı sırasıyla ABS grubu için 16.4 gün, SSD grubu için 19.7 gün ve kontrol grubu için 25.2 gündü $(p<0.001)$. Ortalama enflamatuvar skora göre, ABS grubunda anlamlı bir fark mevcuttu $(p<0.05)$.

TARTIŞMA: Çalışmamız ABS'nin yanık tedavisinde, SSD'ye oranla daha iyi sonuçları olduğunu göstermiştir.

Anahtar sözcükler: Ankaferd Blood Stoper; deneysel çalışma; gümüş sülfadiazin; yanık.

Ulus Travma Acil Cerrahi Derg 2019;25(4):338-342 doi: 10.14744/tjtes.2019.38265 